\title{
A New SNPs at 3'UTR Region of calpain 1 gene and its association with growth and meat quality traits in beef cattle
}

\author{
D. Dairoh ${ }^{1}$, J. Jakaria ${ }^{1}$, M. F. Ulum ${ }^{2}$ and C. Sumantri ${ }^{{ }^{*}}$ \\ ${ }^{1}$ Department of Animal and Production Technology, Faculty of Animal Science, \\ IPB University, Bogor 16680, Indonesia \\ ${ }^{2}$ Department of Veterinary Clinic, Reproduction, and Pathology, \\ Faculty of Veterinary Medicine, IPB University, Bogor 16680, Indonesia \\ *CorrespondingE-mail: ceces@apps.ipb.ac.id
}

Received March 11, 2021; Accepted August 29, 2021

\begin{abstract}
The objective of this study was to evaluate single nucleotide polymorphisms (SNP) in the 3'UTR region of CAPN1 gene by direct sequencing technique in beef cattle and its influence on growth and meat quality of the contrast mode ultrasound image in Bali cattle. The numbers of beef cattle used were Bali cattle ( $\mathrm{n}=52$ heads) which compared to purebred Belgian Blue ( $\mathrm{n}=30$ heads), Limousine ( $\mathrm{n}=14$ heads), Wagyu ( $\mathrm{n}=7$ heads), and PO ( $\mathrm{n}=10$ heads). Genetic diversity data were obtained from calculations by PopGen 1.32 software. Ultrasound imaging of the thoracic longissimus dorsi muscle in Bali cattle was carried out between the $12-13$ ribs, and the sonogram was analyzed by Image-J NIH software. The result shown that 3'UTR of CAPN1 gene was found in six discovery SNPs that polymorphic in Bali cattle, they were g.15284 C $>$ T, g.15347 T>G, g.15525 G>A, g.15853 G>A, g.15905 $\mathrm{G}>\mathrm{A}$, g. $15915 \mathrm{G}>\mathrm{A}$ and Indel mutation was polymorphic in Bali cattle, Belgian Blue, Limousine, and PO. There was no association between these SNPs and growth traits. However, SNP g.15525 G $>$ A was significantly associated $(\mathrm{P}<0.05)$ with a backfat thickness $(\mathrm{BFT})$ in Bali cattle. In conclusion, the CAPN1 gene in Bali cattle is a candidate for Marker Assisted Selection (MAS) related to meat quality.

Keywords: Bali cattle, CAPN1 gene, Growth traits, Meat quality, SNP
\end{abstract}

\section{INTRODUCTION}

Bali cattle (Bos javanicus) is designated as native Indonesian cattle under Regulation No. 18 of 2009 and as a genetic which is come from the domestication of banteng (Bibos banteng) (Martojo, 2012). Bali cattle have the potential to be conserved because as indigenous Indonesian animal genetic resources, they have well adapted to the harsh environmental tropical conditions. The Bali cattle have several advantageous characteristics, including pregnancy rates that range from $80 \%$ to $90 \%$, birth rates of $75-85 \%$ (Wawo,
2018) and carcass values of $56 \%$, and better meat quality (Hafid et al., 2019).

Bali cattle have the potential to be selected as premium beef by the influence of candidate genes related to meat quality and using a molecular approach with evaluating the nucleotide sequence profile in genes, which is the calpains gene (CAPNs). In mammals, calpain is consisting 15 calpain genes family and is mainly localized in the cytosol. Two major calpain genes are found ubiquitously expressed in mammals, namely calpain1 ( $\mu$-calpain) and calpain2 (mcalpain) (Sorimachi et al., 2013). Calpain plays a 
role in post-mortem proteolysis, which can degrade the myofibril and influences meat tenderness by the proteolytic system (Coria et al., 2018). Calpain activity is regulated by calcium levels, and calpastatin is a specific inhibitor (Lian et al., 2013) which is calpain1, and calpain2 requires 3-50 $\mu \mathrm{M}$ and $400-800 \mu \mathrm{M}$ of $\mathrm{Ca}^{2+}$ concentration for the active site, respectively (Goll et al., 2003). About 70\% of CAPN1 is bonded to myofibrils, releasing myofibril protein of actinin, Z-nin and degrades desmin, filament, connectin, nebulin during active in sarcoplasmic (Toit et al., 2013). In cattle, CAPN1 is localized in chromosome 29 (Wang et al. 2019; Pinto et al. 2010), consisting of 21 codings, namely exons and 20 introns of the non-coding (Machado et al., 2010).

CAPN1 gene is well-known as a candidate gene for meat tenderness based on GWAS analysis and reported by Mateescu et al., (2017). About 13 SNPs significant for tenderness were located in a $3 \mathrm{cM}$ region around CAPN1. Moreover, some studied related to the CAPN1 gene had been reported in some cattle (Xin et al., 2011; Sun et al., 2018; Lee et al., 2019), and previous studies had been reported in the same markers in different animal populations in sheep (Machado et al., 2020; Aviles et al., 2013), Pig (Ropka-Molik et al., 2017), and chicken (Shu et al., 2015; Anaas et al., 2016). However, it was limited studied about the non-coding in the 3'UTR region of CAPN1 gene, especially in Bali cattle. The objective of this study was to evaluate the influence of 3'UTR region CAPN1 gene by direct sequencing technique on growth and meat quality traits in beef cattle.

\section{MATERIALS AND METHODS}

\section{Animals and Traits Evaluated}

Blood samples from beef cattle $(n=113)$ were used in this study. The cattle used were Bali cattle $(n=52)$ obtained from BPTU-HPT Denpasar, Bali Province that compared to purebred of Belgian Blue $(n=30)$, Limousine $(n=14)$ from BPTU-HPT Padang Mangatas, Wagyu $(n=7)$, and PO cattle $(n=10)$ from BET Cipelang,
Bogor, West Java Province. This research was conducted at the Laboratory of Animal Molecular Genetics, IPB University. Extraction was carried out by DNA extraction methods using Kit Geneaid. The traits analyzed were growth traits, carcass, and meat characteristics, including longissimus dorsi thickness, backfat thickness, marbling score, and intramuscular fat percentage were measured using a $6.5 \mathrm{MHz}$ transducer of ultrasound images at 12-13 at thoracic vertebrae in Bali cattle with age 23-54 month (Ulum et al., 2014). The USG result data was stored in JPEG format, which was performed by Image-J NIH software (ImageJ, NIH, USA) (Figure 1). The determination of the marbling score (MS) is based on the AUSTRALIAN MEAT and MSA (http://www.wagyu.org.au/marbling/).

\section{PCR Amplification and Sequencing Analysis}

The 3'UTR region of the CAPN1 gene was amplified by designing primer pairs sequence based on GenBank National Center for Biotechnology Information (NCBI) with access code AH009246.3. The primer was as follows: F: 5'CTGCTCTCTATGCCCTCTCT-3', R: 5'TCCAGAGACAAAAGTGGGGT-3' to produce 790 bp polymerase chain reaction (PCR) products. The amplification of the 3'UTR region of CPAN1 gene was carried out using DNA thermocycler AB System machine with the following protocol: predenaturation at $95{ }^{\circ} \mathrm{C}$ for 1 minute, followed by 35 cycles of denaturation at $95^{\circ} \mathrm{C}$ for 15 seconds, annealing at $61{ }^{\circ} \mathrm{C}$ for 15 seconds, extension at $72{ }^{\circ} \mathrm{C}$ for 10 seconds, and with a final extension step at $72{ }^{\circ} \mathrm{C}$ for 3 minutes. PCR products were electrophoresis through $1.5 \%$ agarose gel and were observed using a UV Transilluminator (BioradTM, California, USA). The 790 bp PCR product was sequenced by the $1^{\text {st }}$ Base laboratory service in Selangor, Malaysia. The genotypes of the identified SNPs in the Bali cattle were determined by using Finch TV and Molecular Evolutionary Genetic Analysis (MEGA10) program.

\section{Data Analysis}

Allele and genotypes frequencies, HardyWeinberg equilibrium $(\mathrm{H}-\mathrm{W})$ test, observed $\left(\mathrm{H}_{\mathrm{o}}\right)$, 


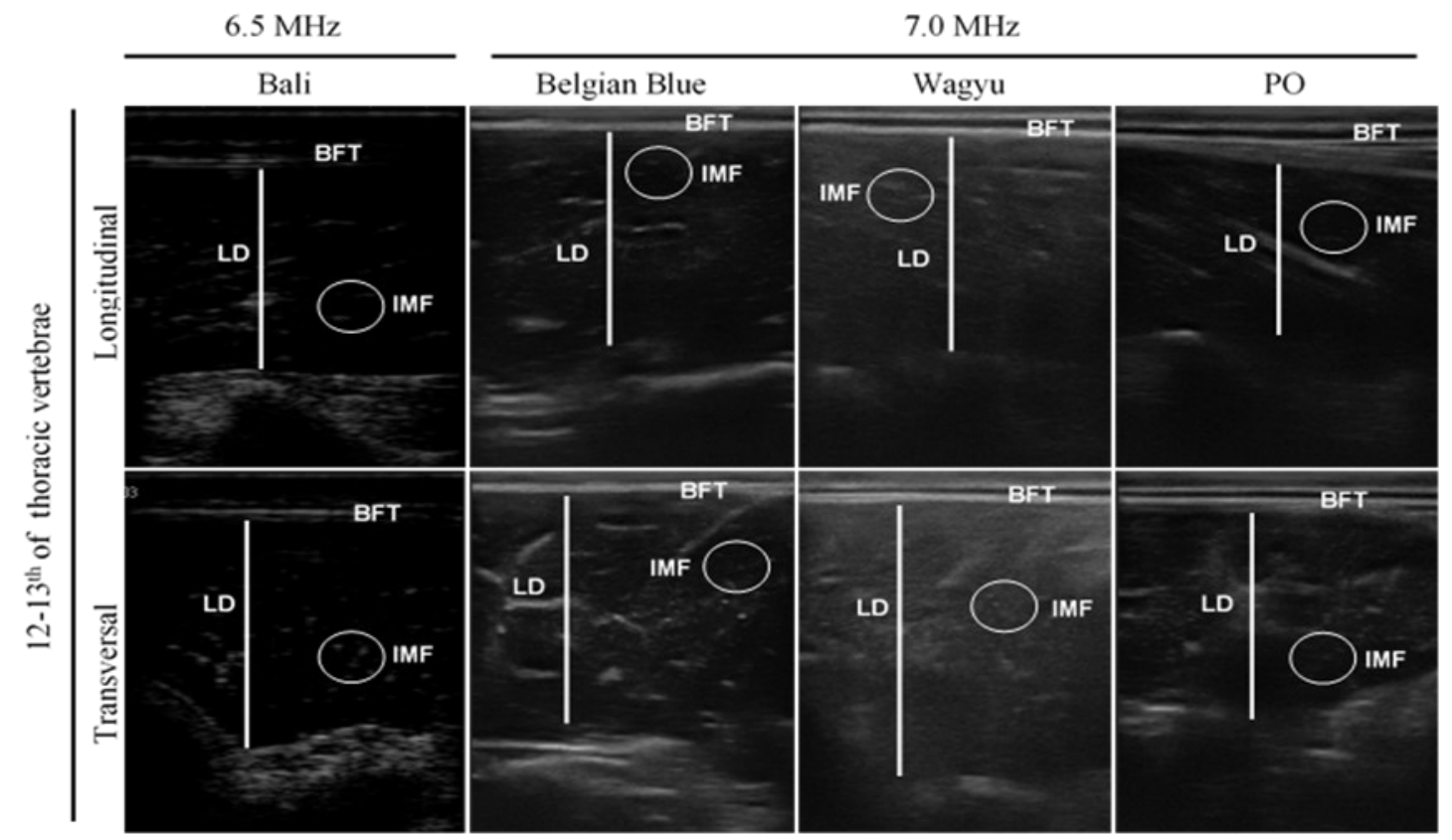

Figure 1. The position of muscle ultrasound measurement on 12-13 ribs orientation point $(\mathrm{BFT}=$ back fat thickness; LD = longissimus dorsi thickness; IMF = intramuscular fat content, and measurement area IMF $30 \mathrm{~mm} \times 30$ $\mathrm{mm}$ )

and expected $\left(\mathrm{H}_{\mathrm{e}}\right)$ heterozygosity of single nucleotide polymorphism were calculated by PopGene 1.32 program. Hardy-Weinberg equilibrium was determined by test. Genetic heterozygosity was determined by observed $\left(\mathrm{H}_{\mathrm{o}}\right)$ and expected $\left(\mathrm{H}_{\mathrm{e}}\right)$ heterozygosity values. The association between each SNPs in CAPN1 gene and carcass and meat characteristic were performed by General Linear Model (GLM) procedure using SAS 9.4 software (SAS Inst, Inc, Cary, NC). The least means square value of genotypes was compared by Tukey Multiple Comparison Test ANOVA. The mathematical of GLM model as follows:

$$
Y i j=\mu+G i+e i j
$$

Where Yij is phenotypic observations (LDT, BFT, MS, IMF); $\mu$ is overall mean; Gi is fixed effect of genotypes; and eij is the random error. This model was used to test for the dominance effect, estimated by the contrast between the effect of the heterozygous genotype and the average effect of the two homozygous genotypes. The significant association was determined by $\mathrm{P}$-value $(\mathrm{P}<0.05)$. Live body weight of
Bali cattle was corrected on age 205 days, 365 days, and 730 days and extensive maintenance using formula according to Hardjosubroto (1994). Moreover, the longitudinal and transversal measurement of ultrasound imaging was also corrected to 34 months of age and extensive maintenance by Salamena and Papilaja (2010) formula as follows:

$$
\begin{aligned}
& \text { Xi corrected }= \\
& \quad\left[\frac{X_{\text {standard }}}{X_{\text {observation }}}\right] \times \text { X observation value } i
\end{aligned}
$$

Where $\mathrm{X}_{\mathrm{i} \text { corrected }}$ is corrected data $\mathrm{i} ; \overline{\mathrm{X}}_{\text {standard }}$ is standard group average; $\overline{\mathrm{X}}_{\text {observation }}$ is observation group average; and $\mathrm{X}_{\text {observation value I }}$ is observation value data $\mathrm{i}$.

\section{RESULTS AND DISCUSSION}

\section{Discovery Single Nucleotide Polymorphism of CAPN1 Gene}

The 3'UTR region was successfully amplified at temperature annealing $60{ }^{\circ} \mathrm{C}$, and the result of PCR product was 790 bp in Bali cattle, 
Table 1. Allele and genotype frequency, heterozygosity, and H-W test SNP CAPN1 gene at 3'UTR region in five populations cattle

\begin{tabular}{|c|c|c|c|c|c|c|c|c|c|c|}
\hline \multirow{2}{*}{$\begin{array}{l}\text { SNPs } \\
\text { g.15284 C>T }\end{array}$} & \multirow[t]{2}{*}{ Populations } & \multirow[t]{2}{*}{$\mathrm{N}$} & \multicolumn{3}{|c|}{$\begin{array}{l}\text { Genotype } \\
\text { Frequency }\end{array}$} & \multicolumn{2}{|c|}{$\begin{array}{c}\text { Allele } \\
\text { Frequency }\end{array}$} & \multirow[t]{2}{*}{$\mathrm{H}_{\mathrm{o}}$} & \multirow[t]{2}{*}{$\mathrm{H}_{\mathrm{e}}$} & \multirow[t]{2}{*}{$\begin{array}{l}\chi^{2} \\
\text { test }\end{array}$} \\
\hline & & & $\mathrm{CC}$ & $\mathrm{CT}$ & TT & $\mathrm{C}$ & $\mathrm{T}$ & & & \\
\hline & Bali & 52 & 0.73 & 0.27 & 0.00 & 0.87 & 0.13 & 0.269 & 0.233 & ns \\
\hline & Belgian Blue & 30 & 1.00 & 0.00 & 0.00 & 1.00 & 0.00 & 0.000 & 0.000 & nc \\
\hline & Limousine & 14 & 1.00 & 0.00 & 0.00 & 1.00 & 0.00 & 0.000 & 0.000 & nc \\
\hline & Wagyu & 7 & 1.00 & 0.00 & 0.00 & 1.00 & 0.00 & 0.000 & 0.000 & nc \\
\hline & $\mathrm{PO}$ & 10 & 1.00 & 0.00 & 0.00 & 1.00 & 0.00 & 0.000 & 0.000 & nc \\
\hline \multirow[t]{6}{*}{ g.15347 T>G } & & & TT & $\mathrm{TG}$ & GG & $\mathrm{T}$ & $\mathrm{G}$ & & & \\
\hline & Bali & 52 & 0.04 & 0.06 & 0.90 & 0.07 & 0.93 & 0.057 & 0.126 & $*$ \\
\hline & Belgian Blue & 30 & 1.00 & 0.00 & 0.00 & 1.00 & 0.00 & 0.000 & 0.000 & $\mathrm{nc}$ \\
\hline & Limousine & 14 & 1.00 & 0.00 & 0.00 & 1.00 & 0.00 & 0.000 & 0.000 & nc \\
\hline & Wagyu & 7 & 1.00 & 0.00 & 0.00 & 1.00 & 0.00 & 0.000 & 0.000 & nc \\
\hline & $\mathrm{PO}$ & 10 & 1.00 & 0.00 & 0.00 & 1.00 & 0.00 & 0.000 & 0.000 & nc \\
\hline \multirow[t]{6}{*}{ g. $15525 \mathrm{G}>\mathrm{A}$} & & & GG & GA & $\mathrm{AA}$ & $\mathrm{G}$ & $\mathrm{A}$ & & & \\
\hline & Bali & 52 & 0.67 & 0.25 & 0.08 & 0.80 & 0.20 & 0.250 & 0.325 & ns \\
\hline & Belgian Blue & 30 & 1.00 & 0.00 & 0.00 & 1.00 & 0.00 & 0.000 & 0.000 & nc \\
\hline & Limousine & 14 & 1.00 & 0.00 & 0.00 & 1.00 & 0.00 & 0.000 & 0.000 & $\mathrm{nc}$ \\
\hline & Wagyu & 7 & 1.00 & 0.00 & 0.00 & 1.00 & 0.00 & 0.000 & 0.000 & nc \\
\hline & $\mathrm{PO}$ & 10 & 1.00 & 0.00 & 0.00 & 1.00 & 0.00 & 0.000 & 0.000 & nc \\
\hline \multirow[t]{6}{*}{ g. $15853 \mathrm{G}>\mathrm{A}$} & & & GG & GA & AA & $\mathrm{G}$ & $\mathrm{A}$ & & & \\
\hline & Bali & 52 & 0.85 & 0.15 & 0.00 & 0.91 & 0.09 & 0.154 & 0.143 & ns \\
\hline & Belgian Blue & 30 & 1.00 & 0.00 & 0.00 & 1.00 & 0.00 & 0.000 & 0.000 & nc \\
\hline & Limousine & 14 & 1.00 & 0.00 & 0.00 & 1.00 & 0.00 & 0.000 & 0.000 & nc \\
\hline & Wagyu & 7 & 1.00 & 0.00 & 0.00 & 1.00 & 0.00 & 0.000 & 0.000 & nc \\
\hline & PO & 10 & 1.00 & 0.00 & 0.00 & 1.00 & 0.00 & 0.000 & 0.000 & nc \\
\hline \multirow[t]{6}{*}{ g.15905 G>A } & & & GG & GA & $\mathrm{AA}$ & $\mathrm{G}$ & $\mathrm{A}$ & & & \\
\hline & Bali & 52 & 0.83 & 0.17 & 0.00 & 0.91 & 0.09 & 0.173 & 0.160 & ns \\
\hline & Belgian Blue & 30 & 1.00 & 0.00 & 0.00 & 1.00 & 0.00 & 0.000 & 0.000 & nc \\
\hline & Limousine & 14 & 1.00 & 0.00 & 0.00 & 1.00 & 0.00 & 0.000 & 0.000 & nc \\
\hline & Wagyu & 7 & 1.00 & 0.00 & 0.00 & 1.00 & 0.00 & 0.000 & 0.000 & nc \\
\hline & $\mathrm{PO}$ & 10 & 1.00 & 0.00 & 0.00 & 1.00 & 0.00 & 0.000 & 0.000 & nc \\
\hline \multirow[t]{6}{*}{ g. $15915 \mathrm{G}>\mathrm{A}$} & & & GG & GA & AA & $\mathrm{G}$ & $\mathrm{A}$ & & & \\
\hline & Bali & 52 & 0.90 & 0.08 & 0.02 & 0.94 & 0.06 & 0.077 & 0.110 & $*$ \\
\hline & Belgian Blue & 30 & 1.00 & 0.00 & 0.00 & 1.00 & 0.00 & 0.000 & 0.000 & nc \\
\hline & Limousine & 14 & 1.00 & 0.00 & 0.00 & 1.00 & 0.00 & 0.000 & 0.000 & nc \\
\hline & Wagyu & 7 & 1.00 & 0.00 & 0.00 & 1.00 & 0.00 & 0.000 & 0.000 & nc \\
\hline & PO & 10 & 1.00 & 0.00 & 0.00 & 1.00 & 0.00 & 0.000 & 0.000 & $\mathrm{nc}$ \\
\hline
\end{tabular}

$\mathrm{SNP}=$ single nucleotide polymorphism; $\mathrm{H}_{\mathrm{o}}=$ observed heterozygosity; $\mathrm{H}_{\mathrm{e}}=$ expected heterozygosity; $\chi^{2}=$ chi-square test; ns $=$ non-significant; $*=$ significant $\left(\chi^{2}\right.$ counted $\left.\geq \alpha 0.05 \mathrm{df} 1: 3.84\right) ; \mathrm{nc}=$ not counted

Belgian Blue, Limousine, Wagyu, and PO (Figure 2). By direct DNA sequencing, the 3'UTR region of CAPN1 gene was obtained six SNPs mutation, namely in the base position g.15284 C>T, g.15347 T>G, g.15525 G>A, g.15853 G>A, g.15905 G>A, and g. $15915 \mathrm{G}>$
A. All these SNPs that found from this study were nucleotide variations with the type of substitution mutations, which is consist of SNP $\mathrm{g}$. $15284 \mathrm{C}>\mathrm{T}$, g. $15525 \mathrm{G}>\mathrm{A}$, g. $15853 \mathrm{G}>\mathrm{A}$, g. $15905 \mathrm{G}>\mathrm{A}$, and g. $15915 \mathrm{G}>\mathrm{A}$ were shown transition mutations and g.15347 $\mathrm{T}>\mathrm{G}$ was a 




Figure 2. PCR amplification of 3'UTR region CAPN1 gene through electrophoresis $1.5 \%$ gel agarose. $M=100$ bp; line 1-6 = samples.

transversion mutation. The result of CAPN1 gene sequencing maps of SNP identification was presented in Figure 3.

The new finding of SNPs in the 3'UTR of CAPN1 gene was specifically found in the Bali sequence and were not found in Belgian Blue, Limousine, Wagyu, and PO sequence. Furthermore, by alignment with complete ensemble sequence of cattle CAPN1 gene using MEGAX software, SNP in 3'UTR of CAPN1 gene was not found based on SNP references source in the access code ENSBTAG00000010230 of Ensembl program.

Single Nucleotide Polymorphism (SNP) is differences of nucleotide in the sequence of genetic material that change the single nucleotide composition at a certain position; however single or more nucleotides insertion and deletion variation (Indel) is not considered as SNP (Brookes, 2007). The type of substitution mutation was divided into two types, namely transition and transversion mutation. Nucleotide change from a purine to purine is known as transition mutation, however, nucleotide change from a purine to pyrimidine or pyrimidine to purine is known as transversion mutation (Luo et al., 2016). Although the nucleotide changes in the 3'UTR re- gion did not change the amino acid, the three untranslated regions contain polyadenylation and RNA binding sites that have an important role in post-transcriptional regulation. This regulation can influence translation efficiency, mRNA stability, and level of the protein product (Mayr, 2017).

\section{Allele and Genotype Frequencies and Chi- Square Test of SNP 3'UTR}

Allele and genotype frequencies of five cattle populations were presented in Table 1. Two alleles in each SNP were found in Bali cattle which was absent in other cattle populations. In Bali cattle, three genotypes were found in SNPs g.15347 T>G, g.15525 G>A, and g.15915 G>A and two genotypes were found in SNPs g.15284 $\mathrm{C}>\mathrm{T}$, g.15853 G>A, and g.15905 G>A. Allele frequencies in the six SNPs identified had a value $\leq 0.99$ in Bali cattle. Therefore, it could be seen that the CAPN1 gene in Bali cattle was polymorphic while monomorphic in Belgian Blue, Limousine, Wagyu, and PO populations. A population is declared as polymorphic if the allele frequency in a large population is about $\leq 0.99$ or $\geq 0.01$ and it was more than one allele found in the population (Allendorf et al., 2013). 



Transition Mutation g.15525 G>A
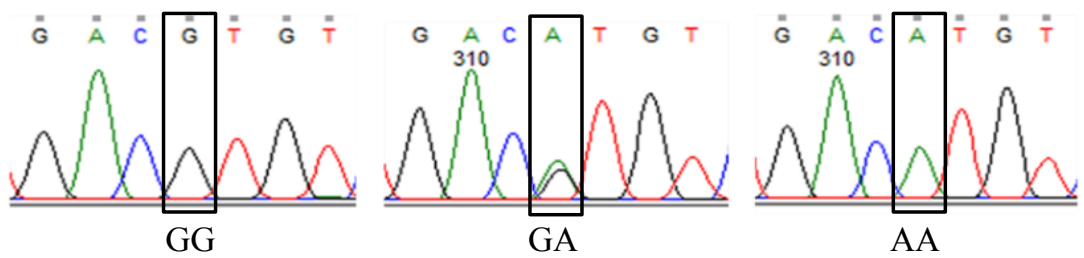

Figure 3. Partial sequencing maps of 3'UTR CAPN1 gene showing transversion and transition mutation in Bali cattle.



(a) Normal

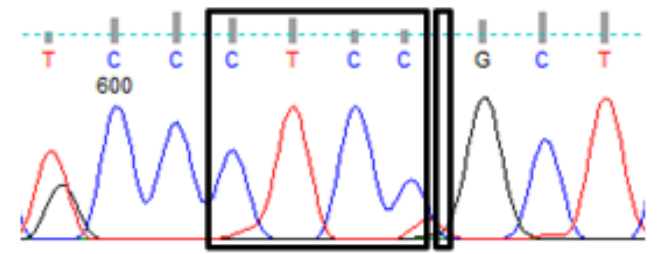

(b) Heterozygous (insertionCTCC/DeletionCTCC)

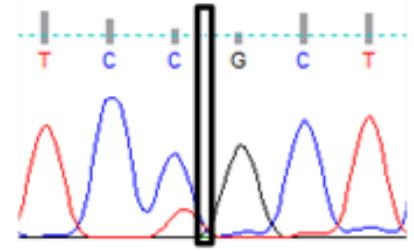

(c) Deletion (15795 - g.15802DelCTCCCTCC)

Figure 4. Deletion mutation maps by sequencing result of 3'UTR CAPN1 gene in beef cattle.

Based on the chi-square test, it was shown that four of six SNPs, including g.15284 C $>\mathrm{T}$, g.15525 G>A, g.15853 G>A, and g.15905 G>A were in Hardy-Weinberg equilibrium $(\mathrm{P}>0.05)$ in Bali cattle, while in Belgian Blue, Limousine, Wagyu and PO populations could not be counted because it was monomorphic. The disequilibrium of SNP polymorphism is caused by three factors, and they are non-random mating, mutation, and selection in the population (Wu et al., 2004).

\section{Discovery of Indel Mutation Polymorphism (g.15795 - g.15802DelCTCCCTCC)}

The 3'UTR region of CAPN1 gene was found eight bases deletion in Bali cattle, Belgian Blue, Limousine, and PO which was caused in- del polymorphism, however in Wagyu was not found this deletion. Three distinct genotypes were found in g.15795-g.15802DelCTCCCTCC including normal $(+/+)$, heterozygous $(+/-)$, and deletion $(-/-)$. The genotype identification of Indel mutation was presented in Figure 4, which shown two distinct genotypes were found in Bali and PO cattle, namely heterozygous and deletion, however in Belgian Blue and Limousine was found two distinct homozygous genotypes, namely normal and deletion.

The result of allele and genotype frequencies, heterozygosity, and chi-square test () of Indel mutation was presented in Table 2. Allele frequency value in Bali cattle, Belgian Blue, Limousine, and PO populations was indicated 
Table 2. Allele and genotype frequency, heterozygosity, and H-W test g.15795 - g.15802DelCTCCCTCC CAPN1 gene at 3'UTR region in five populations cattle

\begin{tabular}{|c|c|c|c|c|c|c|c|c|c|}
\hline \multirow[t]{2}{*}{ Populations } & \multirow[t]{2}{*}{$\mathrm{N}$} & \multicolumn{3}{|c|}{ Genotype Frequency } & \multicolumn{2}{|c|}{$\begin{array}{c}\text { Allele } \\
\text { Frequency }\end{array}$} & \multirow[t]{2}{*}{$\mathrm{H}_{\mathrm{o}}$} & \multirow[t]{2}{*}{$\mathrm{H}_{\mathrm{e}}$} & \multirow[t]{2}{*}{$\begin{array}{l}\chi^{2} \\
\text { test }\end{array}$} \\
\hline & & $+/+$ & $+/-$ & $-1-$ & + & - & & & \\
\hline Sapi bali & 52 & $0.00(0)$ & $0.06(3)$ & $0.94(49)$ & 0.03 & 0.97 & 0.058 & 0.057 & ns \\
\hline Belgian-Blue & 30 & $0.90(27)$ & $0.00(0)$ & $0.10(3)$ & 0.90 & 0.10 & 0.000 & 0.183 & $*$ \\
\hline Limousine & 14 & $0.50(7)$ & $0.00(0)$ & $0.50(7)$ & 0.50 & 0.50 & 0.000 & 0.519 & $*$ \\
\hline Wagyu & 7 & $1.00(7)$ & $0.00(0)$ & $0.00(0)$ & 1.00 & 0.00 & 0.000 & 0.000 & $\mathrm{nc}$ \\
\hline PO & 10 & $0.00(0)$ & $0.50(5)$ & $0.50(5)$ & 0.25 & 0.75 & 0.500 & 0.394 & ns \\
\hline
\end{tabular}

$(+/+)=$ insertion/insertion; $(+/-)=$ insertion/deletion; $(-/-)=$ deletion/deletion; DelCTCCCTCC (deletion 8 bases)

polymorphic, which shown the allele frequency $\geq 1 \%$ (Nei dan Kumar 2000). In addition, the heterozygosity value in Bali and PO was diverse than in Belgian Blue and Limousine populations. Indel mutation found in 3'UTR of CAPN1 gene was a unique and new finding, particularly in Bali cattle. The normal genotype (+/+) that was found in Belgian Blue and Wagyu could be expected that this genotype was carrying better productivity as well as meat production in Belgian Blue and better meat quality in Wagyu. Therefore, it was required more samples of Bali cattle to find a normal genotype, however, the validation of Indel polymorphism identification was required by gene expression based on genotype differences. Indel mutation in 3'UTR had been reported in chicken (Chazara et al., 2011), sheep (Li et al., 2017), pig (Babicz et al., 2008), and cattle (Sutikno et al., 2018). In previously studied, deletion mutation can be caused by the decrease of protein expression, which is encoded in mice ( $\mathrm{Su}$ et al., 2020). The most important that Indel mutation in 3'UTR can be influenced by the protein produced by the translation process of the gene (Steri et al., 2018).

\section{The Association of 3'UTR Polymorphism with Growth and Meat Quality Traits}

Tables 3 and 4 were presented the mean and standard error values for each growth and meat quality of Bali cattle, respectively. The result of the association shown that both SNPs and dele- tion mutation in the 3'UTR polymorphism was not associated $(\mathrm{P}>0.05)$ with growth traits in Bali cattle (Table 3). This result was different from the 5'UTR polymorphism of CAPN1 by previous studies of Sihite et al., (2019) shown that the CAPN1 gene was associated with live weight and daily body weight gain in Bali cattle. The result from this study was in accordance with previously studied by Pintos and Corva 2011; Café et al., 2010 shown that the CAPN1 gene as the major role of flavoring tenderness was a negative effect on growth traits in Argentinian Angus and Brahman cattle. The CAPN1 gene had been studied extensively and it had been reported that SNPs in the CAPN1 gene were significantly associated with carcass and meat quality traits (Liu et al., 2015; Reardon et al., 2010).

The total of six SNPs polymorphism in 3'UTR of CAPN1 gene, only SNP g.15525 G $>$ A significantly had strongly associated $(\mathrm{P}<0.05)$ with backfat thickness in Bali cattle. The highest content of backfat thickness in Bali cattle was carrying the AA genotype, which was not significantly different with Bali cattle carrying GA genotype and the lowest was in Bali cattle carrying the GG genotype (Table 4). This result was indicated that the marbling score and intramuscular fat content increase with increasing backfat thickness in Bali cattle. Backfat thickness is a parameter for identifying carcass fat and also meat in livestock (Gupta et al., 2013). The result of backfat thickness in Bali cattle from this study 
Table 3. Association analysis of SNP and deletion polymorphism at 3'UTR region CAPN1 gene with growth traits in Bali cattle

\begin{tabular}{|c|c|c|c|c|c|c|}
\hline \multirow{2}{*}{ SNPs } & \multirow[b]{2}{*}{ Genotypes } & \multirow[b]{2}{*}{$\mathrm{N}$} & \multicolumn{4}{|c|}{ Growth Traits } \\
\hline & & & $\begin{array}{c}\text { Weaning BW } \\
(\mathrm{kg})\end{array}$ & $\begin{array}{c}\text { BW at } 365 \text { days } \\
(\mathrm{kg})\end{array}$ & $\begin{array}{c}\text { BW at } 730 \text { days } \\
(\mathrm{kg})\end{array}$ & $\begin{array}{l}\text { DBWG } \\
(\mathrm{kg})\end{array}$ \\
\hline \multirow[t]{2}{*}{ g.15284 C>T } & $\mathrm{CC}$ & 35 & $88.46 \pm 18.83$ & $131.93 \pm 39.76$ & $254.60 \pm 68.00$ & $0.31 \pm 0.77$ \\
\hline & $\mathrm{CT}$ & 14 & $92.68 \pm 19.46$ & $128.30 \pm 45.50$ & $256.10 \pm 77.90$ & $0.31 \pm 0.08$ \\
\hline \multirow[t]{3}{*}{ g.15347 T>G } & TT & 2 & $85.00 \pm 05.66$ & $100.29 \pm 8.08$ & $196.50 \pm 10.61$ & $0.25 \pm 0.05$ \\
\hline & TG & 3 & $86.33 \pm 10.69$ & $129.70 \pm 26.00$ & $1256.70 \pm 67.0$ & $0.33 \pm 0.07$ \\
\hline & GG & 44 & $89.93 \pm 19.61$ & $131.73 \pm 42.20$ & $1256.90 \pm 71.0$ & $0.31 \pm 0.08$ \\
\hline \multirow[t]{3}{*}{ g.15525 G>A } & GG & 33 & $89.61 \pm 20.61$ & $130.67 \pm 43.08$ & $260.20 \pm 74.00$ & $0.31 \pm 0.08$ \\
\hline & GA & 13 & $89.31 \pm 16.23$ & $132.40 \pm 40.00$ & $243.20 \pm 64.30$ & $0.30 \pm 0.07$ \\
\hline & AA & 3 & $89.33 \pm 8.02$ & $117.70 \pm 20.20$ & $238.30 \pm 46.50$ & $0.29 \pm 0.04$ \\
\hline \multirow{2}{*}{$\begin{array}{l}\text { g.15795- } \\
\text { 15802Del } \\
\text { CTCCCTCC }\end{array}$} & $+/-$ & 3 & $83.00 \pm 16.46$ & $126.30 \pm 31.30$ & $284.70 \pm 71.60$ & $0.31 \pm 0.07$ \\
\hline & $-1-$ & 46 & $89.93 \pm 18.98$ & $130.58 \pm 41.61$ & $254.80 \pm 70.30$ & $0.31 \pm 0.08$ \\
\hline \multirow[t]{2}{*}{ g. $15853 \mathrm{G}>\mathrm{A}$} & GG & 41 & $89.32 \pm 19.12$ & $128.67 \pm 40.93$ & $253.20 \pm 67.10$ & $0.30 \pm 0.07$ \\
\hline & GA & 8 & $90.50 \pm 17.95$ & $138.80 \pm 41.80$ & $260.30 \pm 86.10$ & $0.34 \pm 0.10$ \\
\hline \multirow[t]{2}{*}{ g.15905 G>A } & GG & 40 & $89.60 \pm 19.13$ & $127.84 \pm 38.24$ & $252.57 \pm 60.59$ & $0.30 \pm 0.06$ \\
\hline & GA & 9 & $89.11 \pm 18.06$ & $141.30 \pm 51.90$ & $262.40 \pm 105.3$ & $0.33 \pm 0.12$ \\
\hline \multirow[t]{3}{*}{ g.15915 G>A } & GG & 44 & $91.16 \pm 18.76$ & $133.15 \pm 42.10$ & $260.00 \pm 70.30$ & $0.32 \pm 0.07$ \\
\hline & GA & 4 & $75.00 \pm 13.95$ & $108.50 \pm 3.87$ & $220.50 \pm 20.40$ & $0.26 \pm 0.04$ \\
\hline & $\mathrm{AA}^{*}$ & 1 & $75.00 \pm 0.00$ & $93.00 \pm 0.00$ & $141.00 \pm 0.00$ & $0.19 \pm 0.00$ \\
\hline
\end{tabular}

$\mathrm{BW}=$ body weight; DBWG = daily body weight gain; ${ }^{*}=$ not involved in the association analysis

was in accordance with the report by Jakaria et al., (2017), which stated that back fat thickness for Bali cattle ranges from 1.59 to $5.39 \mathrm{~mm}$.

The failure of association detection in the several SNPs of Bali cattle populations is suspected by the low of any genotype frequency. It might be the effect of lower frequency genotypes on growth traits and meat quality is small. Further, the monomorphic of Belgian Blue, Limousine, Wagyu, and PO purebred is not supported to estimate their association with growth traits and meat quality. The higher frequency distribution of alleles and its effect on the genotype frequency did not allow a statistical association. Further analysis with the large population should be conducted to better validate association detection in the Belgian Blue, Limousine, Wagyu, and $\mathrm{PO}$ purebred population.

Both Belgian Blue and Limousine had no association with carcass traits and meat quality for the CAPN1 haplotypes (Bennet et al., 2019). In addition, Shi et al., (2011) reported that two significant SNPs A3717G and A3854G in the CAPN1 gene had a significant association with tenderness but not growth traits in Chinese native cattle. However, the g. $232 \mathrm{G}>\mathrm{T}$ polymorphism of the CAPN1 gene in the Bali cattle had an association with not only meat quality (marbling score and intramuscular fat) but also body weight at 730 days (Dairoh et al., 2021). It is limited information about the association between CAPN1 gene with growth trait in beef cattle. It was suspected that the CAPN1 gene was a major candidate gene for selecting meat quality but not for growth traits. This result also provides evidence that no study has conducted an association analysis between SNPs in the 3'UTR region with meat quality and growth traits in other breeds. 
Cheong et al., (2008) and Li et al., (2013) reported that SNP of CAPN1 gene had associated with marbling score and intramuscular fat content in the non-coding of 3'UTR in Hanwoo cattle and the coding of an exon in Angus, Charolais, Hereford, Limousine, and Simmental, respectively. Moreover, Pratiwi et al., (2016) also reported that exon 5-6 of the CAPN1 gene had associated with rump thickness, rump fat thickness, and marbling score. Backfat thickness is one of the parameters that determine the quality of the meat, which can prevent cold shortening during the cooling process that causes meat toughness. As a result, the increasing back fat thickness improves the tenderness of the meat by cooling the carcass more slowly and increases the activity of the proteolytic enzyme, resulting in a better quality of the meat (Dallantonia et al., 2015).

\section{CONCLUSION}

The result confirms that six SNPs were resulted in the 3'UTR region of the CAPN1 gene and were specifically found in Bali cattle. Both all SNPs and deletions found from this study were not associated with growth traits in Bali cattle. On the other hand, an SNP g. $15525 \mathrm{G}>\mathrm{A}$ was associated with backfat thickness by live meat quality prediction using ultrasound imaging in Bali cattle. The information of significantly associated SNPs could be utilized in the Bali breeding program for further genetic improvement of meat quality traits. For the confirmed

Table 4. Association analysis of SNP and deletion polymorphism at 3'UTR region CAPN1 gene with meat quality in Bali cattle

\begin{tabular}{|c|c|c|c|c|c|c|}
\hline \multirow{2}{*}{ SNPs } & \multirow{2}{*}{ Genotypes } & \multirow{2}{*}{$\mathrm{N}$} & \multicolumn{2}{|c|}{ Carcass Characteristics } & \multicolumn{2}{|c|}{ Meat Characteristics } \\
\hline & & & LDT (mm) & BFT (mm) & MS & PIMF (\%) \\
\hline \multirow[t]{2}{*}{ g.15284 C>T } & $\mathrm{CC}$ & 38 & $51.91 \pm 5.05$ & $1.79 \pm 0.31$ & $1.42 \pm 0.58$ & $2.39 \pm 1.39$ \\
\hline & $\mathrm{CT}$ & 14 & $53.09 \pm 3.99$ & $1.82 \pm 0.34$ & $1.41 \pm 0.62$ & $2.43 \pm 1.42$ \\
\hline \multirow[t]{3}{*}{ g.15347 T>G } & TT & 2 & $56.96 \pm 0.73$ & $1.65 \pm 0.17$ & $1.15 \pm 0.32$ & $1.72 \pm 0.74$ \\
\hline & TG & 3 & $49.30 \pm 10.19$ & $1.93 \pm 0.35$ & $1.51 \pm 0.28$ & $2.57 \pm 0.70$ \\
\hline & GG & 47 & $52.22 \pm 4.39$ & $1.79 \pm 0.35$ & $1.42 \pm 0.61$ & $2.44 \pm 1.44$ \\
\hline \multirow[t]{3}{*}{ g.15525 G>A } & GG & 35 & $52.55 \pm 5.82$ & $1.97 \pm 0.53^{\mathrm{b}}$ & $1.51 \pm 0.73$ & $2.69 \pm 1.67$ \\
\hline & GA & 13 & $50.20 \pm 4.21$ & $2.05 \pm 0.30^{\mathrm{a}}$ & $1.67 \pm 0.72$ & $3.22 \pm 1.73$ \\
\hline & AA & 4 & $51.49 \pm 2.88$ & $2.82 \pm 0.48^{\mathrm{a}}$ & $2.13 \pm 1.35$ & $4.13 \pm 3.37$ \\
\hline \multirow{2}{*}{$\begin{array}{l}\text { g.15795- } \\
\text { 15802Del } \\
\text { CTCССТCC }\end{array}$} & $+/-$ & 3 & $52.60 \pm 8.38$ & $1.73 \pm 0.26$ & $1.39 \pm 0.46$ & $2.27 \pm 1.15$ \\
\hline & $-1-$ & 49 & $52.21 \pm 4.62$ & $1.80 \pm 0.35$ & $1.42 \pm 0.60$ & $2.41 \pm 1.41$ \\
\hline \multirow[t]{2}{*}{ g. $15853 \mathrm{G}>\mathrm{A}$} & GG & 44 & $51.99 \pm 4.89$ & $1.82 \pm 0.34$ & $1.45 \pm 0.62$ & $2.50 \pm 1.46$ \\
\hline & GA & 8 & $53.52 \pm 4.15$ & $1.69 \pm 0.35$ & $1.25 \pm 0.34$ & $1.88 \pm 0.79$ \\
\hline \multirow[t]{2}{*}{ g. $15905 \mathrm{G}>\mathrm{A}$} & GG & 43 & $52.02 \pm 4.76$ & $1.81 \pm 0.34$ & $1.45 \pm 0.62$ & $2.51 \pm 1.48$ \\
\hline & GA & 9 & $53.24 \pm 5.02$ & $1.75 \pm 0.34$ & $1.22 \pm 0.35$ & $1.92 \pm 0.74$ \\
\hline \multirow[t]{3}{*}{ g.15915 G>A } & GG & 47 & $52.13 \pm 4.50$ & $1.81 \pm 0.34$ & $1.45 \pm 0.60$ & $2.49 \pm 1.42$ \\
\hline & GA & 4 & $51.77 \pm 7.89$ & $1.62 \pm 0.38$ & $1.09 \pm 0.35$ & $1.57 \pm 0.86$ \\
\hline & $\mathrm{AA}^{*}$ & 1 & $58.70 \pm 0.00$ & $1.90 \pm 0.00$ & $0.87 \pm 0.00$ & $1.67 \pm 0.00$ \\
\hline
\end{tabular}

${ }^{\mathrm{a}-\mathrm{b}}$ Different letters indicate significant difference between genotypes, $\mathrm{P}<0.05$; LDT $=$ longissimus dorsi thickness; $\mathrm{BFT}=$ back fat thickness; MS $=$ marbling score; PIMF $=$ intramuscular fat percentage; ${ }^{*}=$ not involved in the association analysis 
associations, additional studies are encouraged to utilize these SNPs in marker-assisted selection programs.

\section{ACKNOWLEDGMENTS}

This research was financially supported by the PMDSU program with the contract number: 6537/IT3.L1/PN/2020 from Directorate of Research and Community Service, Deputy for Strengthening Research and Development, Ministry of Research, Technology/ National Research and Innovation Agency of the Republic of Indonesia year 2020 .

\section{REFERENCES}

Allendorf, F.W., G.H. Luikart, and S.N. Aitken. 2013. Conservation and the Genetics of Population. Ed 2nd. Wiley-Blackwell Publishing. Britania Raya.

Anaas, A.Y., and M.N.B.A. Manap. 2016. Association between single nucleotide polymorphism of calpainl gene and meat tenderness traits in different genotypes of chicken: Malaysian native and commercial broiler line. International Journal of Nutrition and Food Engineering. 10(2):114-117.

Aviles, C., M. Juarez, F. Pena, V. Domenech, I. Clemente and A. Molina. 2013. Association of single nucleotide polymorphisms in CAPN1 and CAST genes with beef tenderness from Spanish commercial feedlots. Czech. J. Anim. Sci. 58(10):479-487.

Babicz, M., M. Pierzchala, P. Urbanski and I. Rosempolska-Rucinka. 2008. An insertion/ deletion polymorphism in the 3'UTR encoding region of the porcine prolactin (PRL) gene. Anim. Sci. Pap. Rep. 26 (3):183-189.

Brookes, A.J. 2007 Single Nucleotide Polymorphism (SNP). John Wiley \& Sons Ltd. New York.

Bennet, G. L., R. G. Tait, S. D. Shackelford, T. L. Wheeler, D. A. King, E. Casas, and T. P. L. Smith. 2019. Enhanced estimates of carcass and meat quality effects for polymorphisms in myostatin and $\mu$-calpain genes. $\mathrm{J}$.
Anim. Sci. 97:569-577.

Café, L.M., B.L. McIntyre, D.L. Robinson, G.H. Geesink, W. Barendse, D.W. Pethuck, J.M. Thompson and P.L. Greenwood. 2010. Production and processing studies on calpainsystem gene markers for tenderness in Brahman cattle. J. Anim. Sci. 88:3059-3069.

Chazara, O., H.R. Juul-Madsen, C. Chang, M. Tixier-Boichard, and B. Bedhom. 2011. Correlation in chicken between in the marker LEI0258 alleles and major histocompatibility complex sequences. BioMed Central Proceeding. 5(4):S29.

Cheong, H. S., D. H. Yoon, B. L. Park, L. H. Kim, J. S. Bae, S. Namgoong, H. W. 327 Lee, C. S. Han, J. O. Kim, I. C. Cheong and et al. 2008. A single nucleotide 328 polymorphism in CAPN1 asssociated with marbling score in Korean cattle. BioMed Central Genetics. 9:33.

Coria, M. S., G. C. Pedro and A. P. Gustavo. 2018. Calpain System in meat tenderization: A molecular approach. Rev. MVZ Cordoba. 23(1):6523-6536.

Dairoh, D., J. Jakaria, M. F. Ulum, A. B. L. Ishak and C. Sumantri. 2021. Association of SNP g.232 G>T calpain gene with growth and live meat quality prediction using ultrasound images in Bali cattle. Indonesian Journal of Animal and Veterinary Science. 26(2):1-9.

Dallantonia, E.E., J.F. Lage, L.R. Simonetti, E.S. Vito, L.M. Delevatti and T.T. Berchielli. 2015. Effect of rib fat thickness on the quality of aged meat from Nellore young bulls. Acta. Sci. Anim. Sci. 37(2):159-165.

Goll, D.E., V.F. Thompson, H. Li, W. Wei and J. Cong. 2003 The calpain system. Physiol Rev. 83:31-80.

Gupta, S., A. Kumar, S. Kumar, Z. F. Bhat, H. R. Hakeem and A. P. S. Abrol. 2013. Recent trends in carcass evaluation techniques: A review. J. Meat. Sci. 2 (1): 50-55.

Hafid, H., Hasnudi, H.A. Bain, F. Nasiu, Inderawati, P. Patriani and S.H. Ananda. 2019. Effect of fasting time before slaughtering on body weight loss and carcass percentage of Bali cattle. Proceedings, IOP 
Conference Series: Earth and Environmental Science. International Conference on Agriculture, Environment, and Food Security, Medan, Indonesia, October 24-25, 2018. P. 1-7.

Hardjosubroto. 1994. Aplikasi Pemuliabiakan Ternak di Lapangan. Gramedia Widiasarana Indonesia. Jakarta.

Jakaria, H. Hasanah, R. Priyanto, M. Baihaqi and M. F. Ulum. 2017. Prediction of meat quality in Bali cattle using ultrasound imaging. J. Indonesian Trop. Anim. Agric. 42:59-65.

Lee, H.J., S. Jin, H.J. Kim, M.S.A. Bhuiyan, D.H. Lee, S.H. Lee, S.B. Jang, M.H. Han and S.H. Lee. 2019. Validation study of SNPs in CAPN1-CAST genes on the tenderness of muscle (Longissimus thoracic and semimembranosus) in Hanwoo (Korean cattle). Animals. 9:691.

Li, J., S. Erdenee, S. Zhang, Z. Wei, M. Zhang, Y. Jin, $\mathrm{H}$. Wu, H. Chen, X. Sun, H. Xu and et al. 2017. Genetic effect of PRNP gene insertion/deletion (indel) on phenotypic traits in sheep. Prion. 12(1):42-53.

Li, X., M. Ekerljung, K. Lundstrom and A. Lunden. 2013. Association of polymorphisms at DGAT1, leptin, SCD1, CAPN1 and CAST genes with color, marbling and water holding capacity in meat from beef cattle populations in Sweden. Meat. Sci. 94:153-158.

Lian, T., L. Wang and Y. Liu. 2013. A new insight into the role of calpains in postmortem meat tenderization in domestic animal: A review. Asian-Australasian Journal Animal Sciences. 26(3):443-454.

Liu, X., T. Usman, Y. Wang, Z. Wang, X. Xu, M. Wu, Y. Zhang, X. Zhang, Q. Lil and Y. Yu. 2015. Polymorphisms in epigenetic and meat quality related genes in fourteen cattle breeds and association with beef quality and carcass traits. Asian Australas. J. Anim. Sci. 28:467-475.

Luo, G., X. Li, Z. Han, Z. Zhang, Q. Yang, H. Guo and J. Fang. 2016. Transition and Transversion Mutations Are Biased towards GC in Transposons of Chilo suppressalis (Lepidoptera: Pyralidae). genes. 7(10):72.
Machado, L. M., A. N. Meira, E. N. Muniz, H. A. Azevedo, L. L. Countinho, G. B. Mourao, V. B. Pedrosa, and L. F. B. Pinto. 2020. Single loci haplotypes in CAPN1 and CAST genes are associated with growth, biometrics, and in vivo carcass traits in Santa Ines sheep. Ann. Anim. Sci. 20:465-483.

Mateescu, R. G., D.J. Garrick, and J. M. Reecy. 2017. Network analysis reveals putative genes affecting meat quality in Angus cattle. Front. Genet. 8:171.

Mayr, C. 2017. Regulation by 3'-Untranslated regions. Annu. Rev. Genet. 51:171-194.

Nayak, S.N. and V.K. Singh. 2017. Encyclopedia of Applied Plant Science: MarkerAssisted Selection. 2nd Ed. 2:183-187.

Nei, M. and S. Kumar. 2000. Molecular Evolution and Phylogenetics. Oxford Univ Pr. New York.

Pinto, L. F. B., J. B. S. Ferraz, F. V. Meirelles, J. P. Eler, F. M. Rezende, M. E. Carvalho, H. B. Almeida and R. C. G. Silva. 2010. Association of SNPs on 423 CAPN1 and CAST genes with tenderness in Nellore cattle. Genet. Mol. Res. 9:1431-1442.

Pintos, D., and M. Corva. 2011. Association between molecular markers for beef tenderness and growth tarits in Argentinian angus cattle. Anim Genet. 42:329- 332.

Pratiwi, N., Maskur, R. Priyanto and Jakaria. 2016. Novel SNP of calpain-1 (CAPN1) gene and its association with carcass and meat characteristics traits in Bali cattle. J. Indonesian Trop. Anim. Agric. 41:109-116.

PSPK. 2011. Pendataan Sapi Potong, Sapi Perah, dan Kerbau 2011. BPS dan Direktorat Jenderal Peternakan. Jakarta. Indonesia.

Reardon, W., A. M. Mullen, T. Sweeney and R. M. Hamill. 2010. Association of polymorphisms in candidate genes with colour, water-holding capacity, and composition traits in bovine $\mathrm{m}$. longissimus and $\mathrm{m}$. semimembranosus. Meat. 431 Sci. 86:270-275.

Ropka-Malik, K., E. Robert, M. Tyra, K. Piorkowska, M. Oczkowicz, M. Szyndler-Nedza and A. Bereta. 2017. CAPN1 gene as a potential marker for growth performance and 
carcass characteristics in pig. Anim. Prod. Sci. 57:1014-1021.

Salamena, F.J., and J. Papilaja. 2010. Characterization and genetic relationships analysis of buffalo population in MOA island of SouthEast West Maluku regency of Maluku Province. J. Indonesian Trop. Anim. Agric. 35 (2):75-82

Shi, M., X. Gao, H. Ren, Z. Yuan, H. Wu, J. Li, L. Zhang, H. Gao, J. Li and S. Xu. 2011. Association analysis of CAPN1 gene variants with carcass and meat quality traits in Chinese native cattle. Afr. J. Biotechnol. 10 (75):17367-17371.

Shu, J.T., M. Zhang, Y.J. Shan, W.J. Xu, K.W. Chen and H.F. Li. 2015. Analysis of genetic effect of CAPN1 gene polymorphism on chicken meat tenderness. Genet. Mol. Res. 14(1):1393-1403.

Sihite, D. E. W. T., R. Priyanto and J. Jakaria. 2019. Polymorphism and association of 5'UTR CAPN1 gene with growth traits in Bali Cattle by PCR-RFLP. Trop. Anim. Sci. J. 42:175-179.

Sorimachi, H., S. Hata and Y. Ono. 2013. Protein/enzymes structure function and degradation/calpain: Encyclopedia of Biological Chemistry. (H. Sorimachi and Y. Ono, 2 eds). Elsevier Inc. Japan. P.353-361.

Steri, M., M.L. Idda, M.B. Whalen and V. Orru. 2018. Genetic variants in mRNA untranslated regions. Wiley Interdiscip Rev RNA. 9 (4):e1474.

Su, W., Q. Zhou, Y. Wang, A. Chishti, Q.Q. Li, S. Dayal, S. Shiehzadegan, A. Cheng, C. Moore, X. Bi and et al. 2020. Deletion of the capn 1 gene results in alterations in signaling parthways related to alzheimers disease, protein quality control and synaptic plasticity in mouse brain. Front. Genet. 11:334.

Sun, X., X. Wu, Y. Fan, Y. Mao, D. Ji, B. Huang and Z. Yang. 2018. Effects of polymor- phisms in CAPN1 and CAST genes on meat tenderness of Chinese Simmental cattle. Arch. Anim. Breed. 61:433-439.

Sutikno, S., R. Priyatno, C. Sumantri and J. Jakaria. 2016. Polymophism of ADIPOQ and EDG1 genes in Indonesian beef cattle. J. Indonesian Trop. Anim. Agric. 43(4):323332.

Du Toit, E., and J. W. Oguttu. 2013. Calpain and calpastatin activity postmortem and meat tenderness: are two related?. Jurnal of Animal and veterinary Advances. 12:683-688.

Ulum, M.F., E. Suprapto and Jakaria. 2014. U1trasunograpgy image or Longissimus 452 dorci muscle of Bali cattle. Proceeding, KIVNAS PDHI XIII. Konferensi Ilmiah Veteriner Nasional ke-13 Perhimpunan Dokter Hewan Indonesia, Palembang, Indonesia, Nov. 23-26, 2014. P. 368-369.

Wakchaure, R., S. Ganguly, P.K. Praveen, A. Kumar, S. Sharma and T. Mahajan. 2015. Marker assisted selection (MAS) in animal breeding: a review. J. Drug. Metab. Toxicol. 6:e127.

Wang, Z., H. Ma, L. Xiu, B. Zhu, Y. Liu, F. Bordbar, Y. Chen, L. Zhang, X. Gao, H. Gao and et al. 2019. Genome-wide scan selection signatures in Chinese Wagyu cattle using a high-density SNP array. Animals. 9:296.

Wawo, A. A. 2018. Effect of Bulls on Birth Rate and Birth Weight by Using Semi Intensive Bali Cattle Maintenance. CJAH. 3:24-28.

Wu, R., C. Ma, J. Wu, W. Fang and Casella G. 2004. Population genetics of heterosis: effect of hardy-weinberg disequilibrium. Silvae Genetica. 53(1):1-6.

Xin, J., Z. Li-chun, L. Xiao-hui, J. Hai-gao and Y. Chang-gao. 2011. Association of polymorphisms in the calpain 1 gene with meat quality traits in Yanbian Yellow cattle of China. Asian-Aus. J. Anim. Sci. 24(1):9-16. 